\title{
The Cultivation of International Business Ability in Higher Vocational College Against the Backdrop of Cross-border E-commerce Along the "Belt and Road" Initiative*
}

\author{
Huihui Deng \\ Qingyuan Polytechnic \\ Qingyuan, China 511510
}

\begin{abstract}
This paper studied the development of crossborder e-commerce in the context of the Belt and Road Initiative and the demand for talents of cross-border ecommerce enterprises and clarified the development trend of cross-border e-commerce. The author thus understood the urgent need of those enterprises for comprehensive foreign trade talents with international business capabilities, and then analyzed the concept and composition of international business capabilities, based on which recommendations for developing international business capabilities were proposed.
\end{abstract}

Keywords-“Belt and Road" Initiative; cross-border ecommerce; international business ability; cultivation

\section{INTRODUCTION}

At present, with the advent of a new round of science and technology innovation and industrial revolution in the world, cross-border e-commerce technology has been further improved and applied. Driven by the "Belt and Road Initiative", more and more companies are expanding their overseas markets through cross-border e-commerce platforms. Understanding the development of cross-border ecommerce and its urgent need for talents will help clarifying the positioning and direction for talent cultivation.

\section{THE DEVELOPMENT OF CROSS-BORDER E-COMMERCE} UNDER THE CONTEXT OF THE BELT AND ROAD INITIATIVE

Since March 28, 2015 when the "Vision and Proposed Actions Outlined on Jointly Building Silk Road Economic Belt and 21st-Century Maritime Silk Road" issued by the

*Project Source: 2016 Qingyuan Polytechnic Social Science Project (No. SK16002): Research on the Mechanism of E-Commerce Development - Taking Qingyuan as an Example; 2017 Guangdong Higher Vocational and Technical Education Research Association Project (No. GDGZ17Y033 Dynamic Docking of Higher Vocational Professional Structure and Regional Industrial Structure in the Pearl River Delta Urban Agglomeration

- Based on the Perspective of Urban Function Specialization; 2017

Higher Vocational Education Business Professional Teaching Steering Committee of Guangdong Province Project (No. YSYJZW2017YB12)

Research and Practice of Professional Core Competence of Cross-border Ecommerce in Higher Vocational Education under the Background of "Belt and Road" - An Empirical Analysis Based on WICS Model
National Development and Reform Commission, the Ministry of Foreign Affairs and the Ministry of Commerce, the cross-border e-commerce as an important pioneer and cutting edge for the "Belt and Road" Initiative have made great progress. According to statistics: during 2014 to 2017 , China's cross-border e-commerce transactions have doubledigit growth, and the proportion of China's foreign trade transactions has continued to rise, accounting for $29 \%$ of total imports and exports (see "Table I").

TABLE I. ANNUAL CROSS-BORDER E-COMMERCE TRANSACTION DATA

\begin{tabular}{|l|l|l|l|}
\hline Year & $\begin{array}{c}\text { Trading Scale } \\
\text { (Trillion Yuan) }\end{array}$ & $\begin{array}{c}\text { Growth Rate } \\
(\%)\end{array}$ & $\begin{array}{c}\text { As percentage } \\
\text { of China's } \\
\text { Import and } \\
\text { Export (\%) }\end{array}$ \\
\hline 2008 & 0.8 & & 4.6 \\
\hline 2009 & 0.9 & 9.2 & 6.0 \\
\hline 2010 & 1.3 & 41.0 & 6.3 \\
\hline 2011 & 1.8 & 40.1 & 7.5 \\
\hline 2012 & 2.3 & 32 & 9.6 \\
\hline 2013 & 3.1 & 31.3 & 4.6 \\
\hline 2014 & 4.0 & 30.6 & 11.9 \\
\hline 2015 & 5.4 & 28.6 & 22.0 \\
\hline 2016 & 6.7 & 24.0 & 27.54 \\
\hline 2017 & 8.06 & 20.3 & 29 \\
\hline
\end{tabular}

As reported in www.Chcyxx.com, Cross-border ecommerce exports in 2017 continued to grow rapidly. Especially in the past four years, although the annual compound growth rate of traditional foreign trade exports was minus $7 \%$, as the Belt and Road Initiative has been increasingly recognized by the international community, the overall annual compound growth rate of cross-border ecommerce exports was $31 \%$; the export $\mathrm{B} 2 \mathrm{~B}$ growth rate was $29 \%$; and the export B2C growth rate was $43 \%$. 


\section{ANALYSIS OF TALENT DEMAND IN CROSS-BORDER E- COMMERCE INDUSTRY}

With the rapid development of the cross-border ecommerce industry and the diversification of the crossborder e-commerce market, the demand for talents is becoming more and more urgent. It's estimated there were around 400,000 companies with foreign trade export rights in 2014 in China. As more and more traditional enterprises enter the field of cross-border e-commerce, this figure is still rising. According to the average proportion of talents owned by companies with import and export rights in China, China needs at least 2 million compound talents who know both the cross-border e-commerce and the foreign trade.

The cross-border e-commerce major has just been established recently, and it is still in an exploratory period. It has not formed a relatively mature talent training model, and the cross-border e-commerce talent training scale is not able to fit the development of foreign trade. Most of the graduates recruited in the cross-border e-commerce industry come from Majors such as International Trade, E-commerce and Business English. However, the professional knowledge structure of each major is relatively simple, and the problemsolving ability and practical operation ability cannot meet the needs of those cross-border e-commerce enterprises.

In order to better understand the urgent needs of crossborder e-commerce enterprises for talents, interviews and investigations were conducted among 54 such enterprises. This survey is mainly based on private enterprises, as well as some joint ventures and wholly-owned enterprises.

\section{A. Analysis of Enterprises' Urgent Needs}

According to the conclusions of interviews and investigations of these cross-border e-commerce companies, the most urgently needed positions of enterprises (see "Fig. 1") are foreign trade salesmen, followed by cross-border platform operators, foreign trade assistants, business followup personnel, while the demand for simple customs brokers, negotiators and documentary personnel for foreign trade is zero. It can be seen that in the cross-border e-commerce industry, the ability to promote products, to collect market information, to analyze and develop customer, and to be familiar with the entire foreign trade business processes (negotiating business, signing contract, fulfilling contracts, tracking and settling business). With the development of cross-border e-commerce, the demand for cross-border ecommerce platform operators who are familiar with platform product design, platform rules and other operations is also increasing, which also reflects those companies' need for cross-border e-commerce talents tends to be compound talents with e-commerce and international business capabilities.

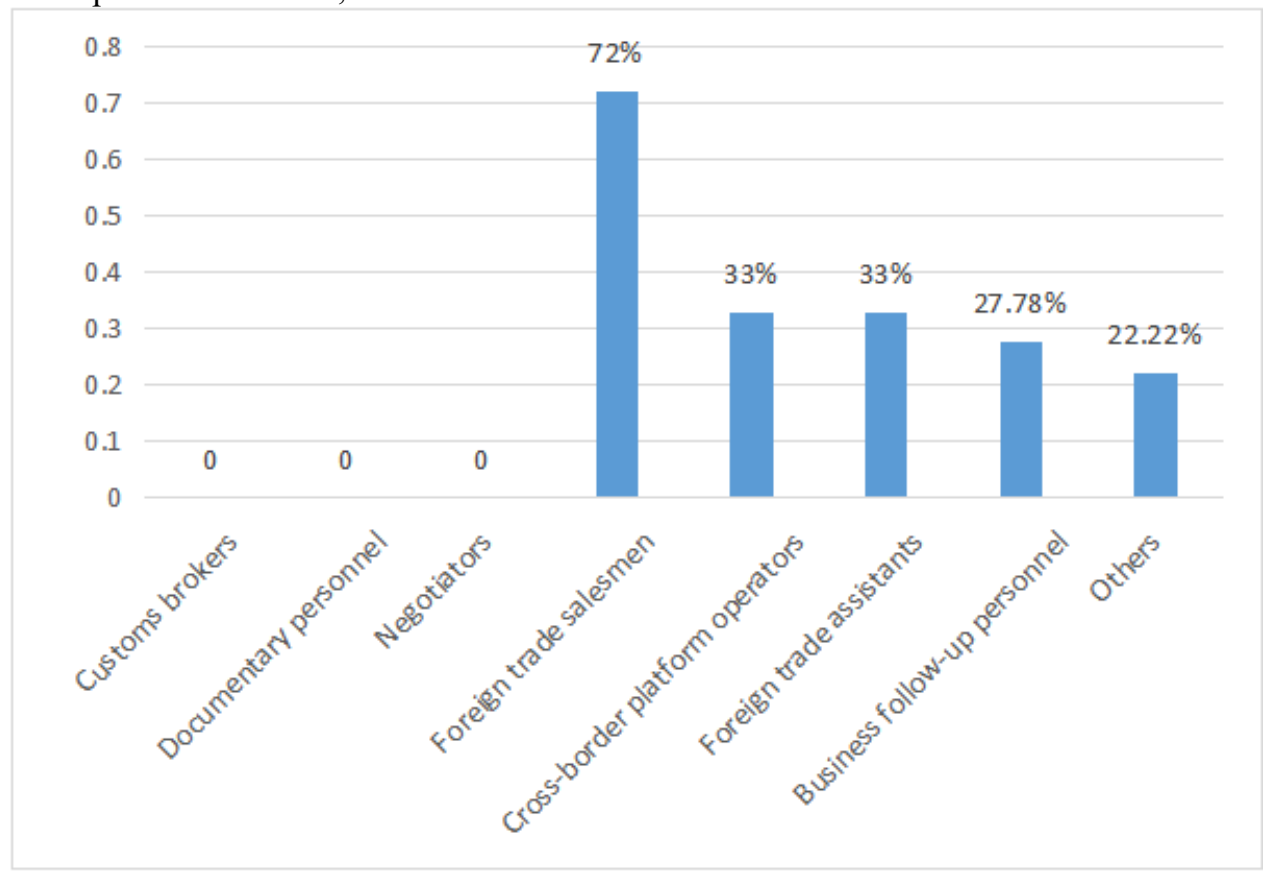

Fig. 1. Cross-border e-commerce companies' urgent needed positions analysis.

\section{B. Analysis of Enterprises' Needed Skills}

When recruiting foreign trade personnel, cross-border ecommerce companies attach the most attention to the foreign language level and cross-cultural communication and coordination ability of job candidates (see "Fig. 2"), followed by the ability of market development, contract negotiation, and order handling abilities. It can be seen that the enterprises engaged in cross-border e-commerce mainly wants to hire personnel with English competence and communication ability. This also explains the reason why cross-border e-commerce enterprises need candidates to obtain English College English Test band 4 or higher English qualification certificate as one of the employment conditions. In addition, the abilities to develop customers, to handle orders, to fulfill platform operations, to negotiate business 
contract and to follow up other international business operations are also important factors in the recruitment of

those enterprises.

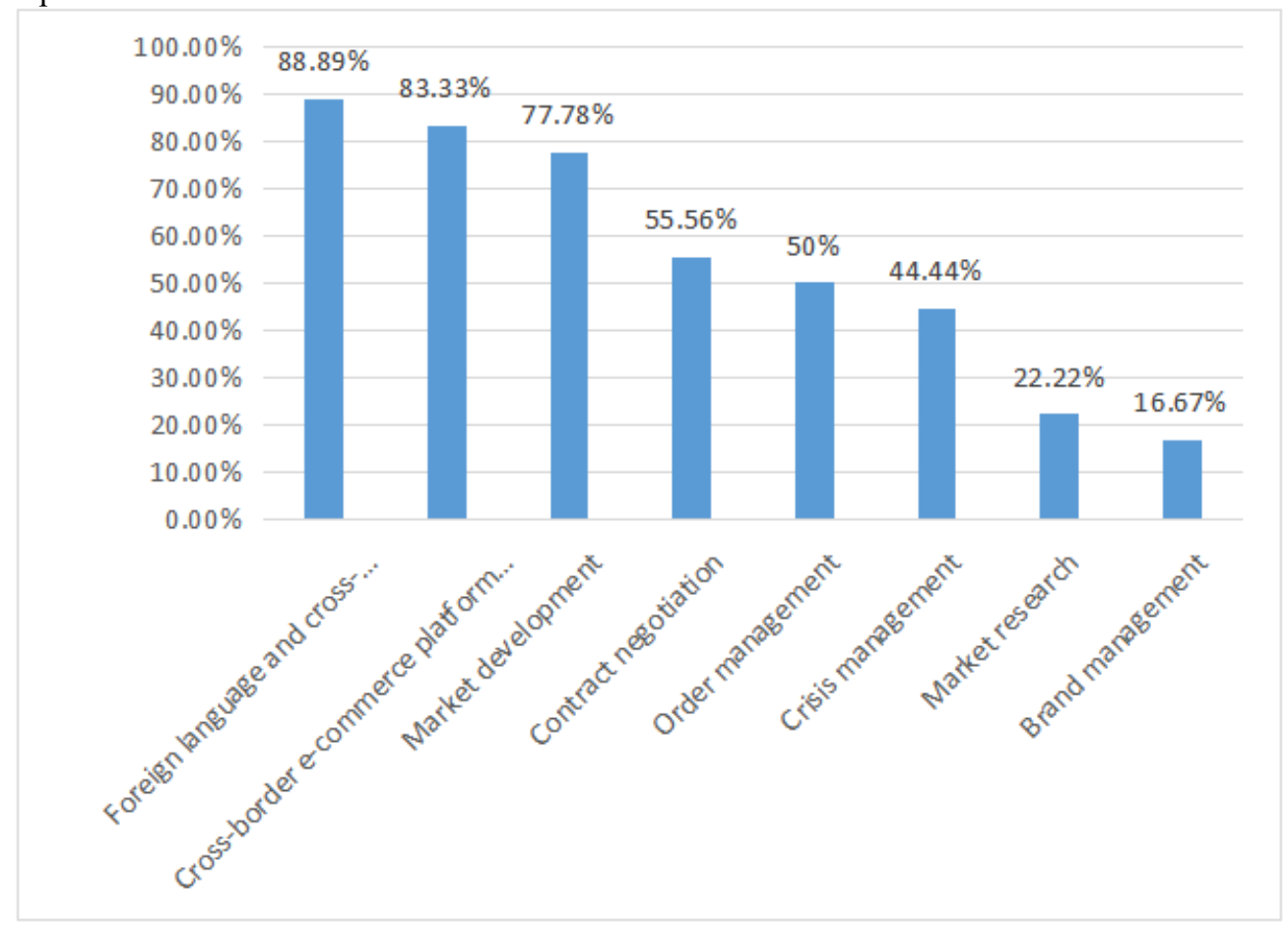

Fig. 2. Cross-border e-commerce companies' urgent needed abilities analysis.

\section{INTERNATIONAL BUSINESS ABILITY AND ITS COMPOSITION}

\section{A. Concept of International Business Ability}

International business ability refers to the capability to maximize the benefits of global resources. However, most International Business majors in colleges and universities focus only on nurturing students' traditional foreign trade operation and cross-cultural communication ability, ignoring the changes and development of the foreign trade situation. This ignorance results in the incompatibility of the concept of international business ability and the social needs, which leads to the inferior and inadequate development of the talent training model.

Due to the new development trend of cross-border ecommerce in China's foreign trade, operational capabilities related to international cross-border e-commerce should be added in international business abilities besides traditional foreign trade operations and cross-cultural communication capabilities.

\section{B. Reconstruction of International Business Abilities}

Foreign trade business operation ability, as the basic requirement of foreign trade salesmen, refers to the abilities needed through traditional foreign trade procedures such as participating exhibition, writing business correspondence, negotiating business contract, checking prices, handling orders, dealing with shipment and insurance, settling commodity inspection and customs declaration, and etc.. In addition, cross-border e-commerce related capabilities should be embedded in the composition of international business abilities, which should include e-commerce product development and brand management, online cross-border customer development and maintenance, international network payment method, risk identification and management, international logistics selection, and the adaptation to various cross-border e-commerce platform rules. Through the inductive analysis of the above processes and specific operations, a form of international business capability is formed and the corresponding courses: 
TABLE II. INTERNATIONAL BUSINESS ABILITY COMPOSITION

\begin{tabular}{|c|c|c|}
\hline International business ability & Corresponding Tasks & Corresponding courses \\
\hline $\begin{array}{l}\text { Overseas market development and } \\
\text { maintenance }\end{array}$ & $\begin{array}{l}\text { Exhibitions, online resources and other } \\
\text { tools can be used to obtain overseas } \\
\text { information about market and customers } \\
\text { conditions. Business contacts and } \\
\text { relation can be established and } \\
\text { maintained through email, phone call } \\
\text { and other instant communication } \\
\text { software. }\end{array}$ & International Marketing \\
\hline $\begin{array}{l}\text { Product development and brand } \\
\text { management }\end{array}$ & $\begin{array}{l}\text { Proper products are selected in } \\
\text { accordance with overseas market } \\
\text { conditions, appropriate brand names and } \\
\text { brand management methods can be } \\
\text { chosen. }\end{array}$ & $\begin{array}{lcc}\text { International } & \text { Trade } & \text { Practice, } \\
\text { International Marketing } & \end{array}$ \\
\hline Cross-border platform operations & $\begin{array}{l}\text { According to the rules and } \\
\text { characteristics of different cross-border } \\
\text { platforms, products, image, international } \\
\text { logistics, payment methods price } \\
\text { calculation methods are chosen. }\end{array}$ & $\begin{array}{l}\text { Online Foreign Trade Practice, Cross- } \\
\text { border E-commerce Practice }\end{array}$ \\
\hline Business Negotiation & $\begin{array}{l}\text { According to the market and products } \\
\text { situation, prices are calculated, different } \\
\text { business terms such as payment, } \\
\text { shipment, insurance, inspection, quantity } \\
\text { and etc. are negotiated through different } \\
\text { communication tools. }\end{array}$ & $\begin{array}{l}\text { International } \quad \text { Trade } \\
\text { International Documentation Practice }\end{array}$ \\
\hline Trade risk prevention and settlement & $\begin{array}{l}\text { Different payment methods and tools } \\
\text { including the traditional and the online } \\
\text { ones can be selected in accordance with } \\
\text { different situations such as market, } \\
\text { product, exchange rate and cross-border } \\
\text { platform. And proper risk prevention } \\
\text { can be carried out. }\end{array}$ & $\begin{array}{l}\text { International Settlement, Documentation } \\
\text { Practice, International Trade Practice }\end{array}$ \\
\hline Performance of trade contracts & $\begin{array}{l}\text { A reasonable logistics and transportation } \\
\text { method and insurance for the goods can } \\
\text { be chosen, transportation and insurance } \\
\text { contracts should be signed; business } \\
\text { processes such as inspection, customs } \\
\text { declaration, shipment, and settlement of } \\
\text { foreign exchange according to the } \\
\text { contract can be handled. }\end{array}$ & $\begin{array}{l}\text { International Logistics and Cargo } \\
\text { Insurance, Customs Declaration and } \\
\text { Inspection, }\end{array}$ \\
\hline $\begin{array}{l}\text { Cross-cultural oral and written } \\
\text { communication }\end{array}$ & $\begin{array}{l}\text { Cross-cultural awareness, cultural } \\
\text { understanding and empathy for different } \\
\text { markets can be applied and business } \\
\text { negotiation and daily English } \\
\text { communication can be done smoothly. }\end{array}$ & $\begin{array}{l}\text { Intercultural Communication, Listening } \\
\text { and Spoken English, Writing of Foreign } \\
\text { Trade Correspondence }\end{array}$ \\
\hline
\end{tabular}

\section{Cultivation of InTERnAtional Business ABILITy}

According to the above-mentioned ability composition analysis, it is possible to construct and design training ideas and methods from the aspects of curriculum system, teaching mode, practical teaching, and collaborative education.

\section{A. Reforming Course Content and System According to the Dynamic Needs of Talents}

The current curriculum system is the accumulative hard work and summary of many years of teaching and research. Therefore, the reform of the curriculum system is not a complete negation or a fresh start, but the adjustment, optimization and expansion of the former curriculum system. After clearly conforming to the knowledge and skills contained in the new industry and the new business format, the curriculum system of international business ability training is fully reconstructed according to the order and difficulty level, in order to adapt to the new normal enterprise's demand for compound foreign trade talents.

In order to cultivate new skills, the different aspects of cross-border e-commerce and traditional foreign trade business will be sorted out, the links between different courses and cross-border e-commerce industry should be clarified and new knowledge and skills should be added to supplement the original curriculum content. For Example: In the course of "International Trade Practice" , when teaching the subject matter of the contract, the concept and skill of product quality management and brand development management can be included; while teaching the traditional price calculation in import and export business, the principles and techniques of branded product pricing should be introduced. In the course of "International Documentation Practice", besides teaching international trade settlement instruments and settlement methods, tools and techniques 
about risk prevention and management such as China Export and Credit Insurance Corporation can be added.

For those knowledge and skills that were not involved in the original courses, a new course can be set up to supplement the original curriculum. Especially the crossborder platform operation ability showed in the abovementioned Table 2, were missed from the programme of International Business majors in some higher vocational colleges and universities, courses like Online Foreign Trade Practice or Cross-border E-commerce Practice can be added to fit the target students.

\section{B. Project Teaching Mode and Integrated Evaluation Mode}

Based on professional needs, "theory-practice integration teaching" idea and "task-driven" teaching mode should be formed, with the jointly collaborative training pattern among government, industry, and schools as the carrier, which means that government, cross-border e-commerce industries and higher vocational schools should work together to adjust the out-dated contents and knowledge to suit the rapid change and development of international business practice and operation. First of all, the design of situational classroom activities can have students experience simulated scenarios, for example, the real business negotiation email can be brought into the classroom, and students can analyze the problems and thus solve them. Secondly, modular series scenarios can be created, such as breaking the task of international salesman into several instructional designs from market research, customers' development, product selection, business negotiation, contract execution to international business settlement in accordance with the cognitive characteristics of students. Different teaching contents and project tasks should be designed to fit various situational teaching modules. Task-driven project thus is created and students can learn effectively through this situationalexperiencing project to simulate the real business work environment. Finally, online teaching system for international business should be established. With the spread of multimedia and information technology (such as the fragmented modular micro-class), a complete crossinternational business curriculum online system can be form to provide rich learning resources for students. The openness of the network can be used to create the cognitive situation with the aim of guiding students to solve the problems in theory learning and practice independently, so as to achieve the unification of the construction and the practice of international business knowledge.

\section{CONCLUSION AND SUGGESTIONS}

The change of teaching mode is only the beginning of talent training. Finally, it is necessary to carry out a scientific comprehensive evaluation of the learning effect of students and realize the reform of students' assessment. Since international business ability is a kind of comprehensive practical application ability, international business graduates are required to have a variety of professional basic knowledge, strong practical operation ability and professional adaptability. Therefore, the reform on assessment of the curriculum effectiveness should be based on a comprehensive diversified combination assessment. It is possible to design a comprehensive curriculum evaluation mechanism for integrating teachers' assessment of professional knowledge mastered by each individual student in each sub-project, and at the same time, the performance of students' comprehensive practical training project should take into consideration while assessing their comprehensive skills in international business operations. The real work task evaluation criteria of relevant cooperative enterprises can be introduced into this mechanism to review all aspects of students' project works, and the preferred works can even be provided to those relative enterprises for practical application or for obtaining their appraisal on finisher' tasks performance and their comprehensive business abilities. In this way, students' ability to put theoretical knowledge into practice can be truly evaluated. For those courses with on-campus training platform, the scores of the platform can also be added. Furthermore, students' participation in professional technical competitions such as Practice for Operational Competence in International Business (POCIB) and crossborder e-commerce can be a part of such comprehensive assessment.

Students with the comprehensive assessment criteria in their mind can pay more attention to those practical activities and training, so that they will try to work out the relative theories involved in practice and training.

\section{A. Putting Theory into Practice and Putting Practice into Training}

International business ability is the comprehensive quality that international business participants demonstrate when they complete international business goals or specific tasks. This ability can only be linked to the completion of international business-related practical activities. Without specific practices and training, those abilities cannot be developed. Therefore, in cultivating international business abilities, it is necessary to strengthen the practice of teaching, try to drop off the less relevant theoretical courses, and change the purely theoretical programme into the practical one or the integrated application of theory and practice, and increase the participation of students in international business activities. The hours and credits of such practical activities, as well as the practical assessment in each course should be carefully planned to be included in the evaluation system.

In some practical course, entrepreneurs and celebrities from cross-border e-commerce industry can be invited to conduct lectures to enhance students' understanding of this industry, and then to provide direction for students' learning and to improve students' ability to connect theory with practice.

The vigorous development trend of cross-border ecommerce has also facilitated the cultivation of relevant professionals. The platformization of cross-border ecommerce business model and the dataization of products are more conducive to the design and development of practical training. Each relative course can base its practical teaching and training system on the knowledge structure and 
skill requirements of its course, thus practice project with cross-border e-commerce characteristics can be designed.

Some courses tend to be much relative to the crossborder e-commerce industry, and even the entire process of cross-border e-commerce can be integrated into specific training programs while designing the entire teaching plan. Such training programs should focus on practicability and operability and require a combination of theory and practice. In terms of methods, in addition to interactive teaching modes such as group discussion, case analysis, simulation company, and project presentation, it is necessary to have comprehensive practical training, for example, building an on-campus training platform for teaching where theory can be put into practice have students simulate the real workflows and work tasks of the cross-border e-commerce. The training platform should try to converge with the current mainstream cross-border e-commerce platform, simulate the real working environment of the cross-border e-commerce enterprise as much as possible, and let the students carry out simulation operations on the training platform with different identities. With the monitoring function of the platform, the whole process of practice can be tracked, therefore, students quickly get to know their weakness, and thus it is easier for students to master the operation skills in this simulated crossborder e-commerce business working environment. Their core competitiveness of practical work can be enhanced in this training mode.

\section{B. Cooperation Among Schools, Government, Enterprises, Industry and Research Institutes}

Since cross-border e-commerce enterprises have more indepth understanding of the requirements and the job responsibilities of positions concerning foreign trade, therefore, the opinions of experts in those companies should be referred to, when the revision of training program and curriculum is to be made. In particular, focus should be on establishing long-term friendly cooperative relationships with cross-border e-commerce companies which enjoy strong technical strength or engage in local traditional industries, thus a collaborative education system that is deeply relative with local industry or have strong tie with powerful enterprises will be formed.

However, only bringing in cross-border e-commerce enterprises or even industry is not enough. More parties such as government, schools, enterprises, relevant industry and research institutes should take a role in the talents cultivation of these urgent needed personnel which create diversified cooperation at different levels to realize students' training transformation from single basic skills to comprehensive competence. Corporate culture experience center, practice center, training and internship base with different crossborder e-commerce companies or industry associations should be built, at the same time different cooperation mechanisms should be worked out to fit various conditions. In this way, the gap between various practices to the actual work can be narrowed.

Finally, through the government's policy guidance and support in cross-border e-commerce, it is feasible for schools to conduct practical research together with other sister institutions and scientific research institutions.

\section{REFERENCES}

[1] Chen Jian. On Reorientation of Core Courses in Higher Vocational Education under the Background of "Internet +"[J]. Modern Vocational Education. 2017(9):106-107.

[2] Yang Yafen.A Probe into Unique Talents Cultivation Model of International Trade Specialty in Colleges \& Universities: A Case Study of Cross-Border E-Commerce [J]. Journal of Hangzhou Dianzi University (Social Sciences). 2017(5): 69-73.

[3] Du Fengrui. Analysis of talent demand of foreign trade enterprises under the background of cross-border e-commerce [J]. Guangxi Education. 2017(47): 115-116.

[4] Cai Xiaoyong, Chen Chen, Yu Zipeng. The Study of Job Market Requirements for the International Business Capability of College Graduate from the Discipline of International Economics and Trade under the New Normal Economics - Based on the Analysis of the Questionnaire Survey Results[J]. Journal of Southwest China Normal University (Natural Science). 2015(10): 124-128.

[5] Analysis of the Status Quo and Development Prospects of China's Cross-border E-commerce Market in 2017[R/OL].http://www.chyxx.com/industry/201712/598133.html. 2017.12.28. 